\title{
LA FICCIÓN EN PLATÓN
}

\author{
Ivana Costa ${ }^{1}$ \\ Universidad de Buenos Aires - Universidad Católica Argentina - Universidad \\ Nacional de Tres de Febrero (Argentina)
}

Recibido: 06.10.2018 - Aceptado: 21.11.2018

\begin{abstract}
RESUMEN
La filosofía emplea ficciones de maneras diversas: metáforas, hipótesis, experimentos mentales, postulados, cuya falsedad teorética se admite pero que se emplean no obstante por su valor práctico, incluso como forjadores de racionalidad. Platón no es ajeno a este procedimiento, y lo emplea profusamente a lo largo de su obra. Este trabajo consta de dos partes: en la primera se lleva a cabo un rápido repaso por la historia semántica de la noción de ficción (a partir del núcleo lexical plássō/plásma) con el objetivo de subrayar la relevancia filosófica de las connotaciones allí implícitas. En segundo lugar se argumenta en favor de la pertinencia de leer como "ficción" la referencia de Platón a cierto tipo de falsedad -que podríamos llamar la falsedad consciente- en República II y III.
\end{abstract}

Palabras clave: Platón; ficción; verdad; falsedad.

\begin{abstract}
In philosophy, fictions are employed in different manners: metaphors, hypothesis, mental experiments and postulates, whose theoretical falsity is admitted, but which are nonetheless used because of their practical value, or because they can contribute to shape rationality. This procedure is not alien to Plato, who employs fictions profusely in his dialogues. This paper has two parts: the first one makes a quick review of the history of the meanings of "fiction" (focusing the lexical family of plassō/plasma) in order to underline the philosophical relevance of its connotations. In the second one, I argue in favor of reading "fiction" to refer to one of the two senses of falsity -a sense we could call conscious falsity- that Plato distinguishes in Republic II-III.
\end{abstract}

Keywords: Plato; fiction; truth; falsity.

\footnotetext{
1 ivanac@hotmail.com
} 


\section{FILOSOFÍA Y FICCIÓN}

Habitualmente asociamos la palabra ficción con la invención literaria. En el habla coloquial estas dos nociones aparecen con frecuencia como indisociables. En ámbito filosófico, sin embargo, la noción de ficción adquiere otra complejidad y sobre todo un campo de aplicación mucho más amplio. Para la filosofía, más allá del contenido inventado de algunas piezas literarias (cuentos, novelas, poesías, mitos), hay ficciones de muy diverso tipo: elaboraciones, creaciones de un punto de vista que no tiene realidad empírica pero que proporciona potencia teórica, o también práctica y decisoria. Así entendidas, resultan ser ficciones muchas hipótesis, axiomas y postulados científicos; conceptos que -bien mirados- son en verdad ilusiones (de continuidad, unidad, identidad, fisicidad) pero no ilusiones evasivas, ya que contribuyen a forjar racionalidad, como las ficciones de las matemáticas y las del derecho. Su valor ha sido señalado desde la Antigüedad, a lo largo de toda la historia de la filosofía, y especialmente en tiempos modernos. En las últimas décadas, el interés de esta clase de ficciones para la epistemología, la ontología, la lógica, la filosofía del lenguaje y de la mente ha sido manifiesto y sostenido. ${ }^{2}$ Sin embargo, quien planteó la virtual omnipresencia de las ficciones en la filosofía y en nuestra vida fue Hans Vaihinger, hace ya más de un siglo.

En Die Philosophie des Als $\mathrm{Ob}$, Vaihinger argumenta que nuestro acceso a lo real está mediado casi siempre por sistemas de pensamiento que, suponemos, se adecúan a la realidad; siguiéndolos, actuamos "como si" la realidad efectivamente se adecuara a aquellos sistemas. Vaihinger llama ficcionalismo a la convicción de que "una idea cuya no-verdad o incorrección, es decir, cuya falsedad teorética ha sido admitida, no carece por esa razón de valor práctico ni de utilidad, pues esa idea, a pesar de su nulidad teorética, puede tener gran relevancia práctica". ${ }^{3}$ Notables anticipaciones del ficcionalismo encuentra Vaihinger en

${ }^{2}$ Nelson Goodman en Fact, Fiction and Forecast (1956); Hillary Putnam en Ethics Without Ontology (2002) y en diversos trabajos publicados en los tres volúmenes de sus Philosophical Papers (1975, 1978 y 1983); John Searle en The Construction of Social Reality (1995); Hartry Field en Truth and the Absence of Fact (2001) y en Science Without Numbers. A Defense of Nominalism (2016); por tomar solo algunos ejemplos; Jean-Pierre Cléro, en Les raisons de la fiction (2004) y Essaisur les fictions (2014).

3 Cf. Vahinger 1935, viii. Se trata del prefacio a la primera edición inglesa (1924), The Philosophy of 'As if'. A System of the Theoretical, Practical and Religious Fictions in Mankind, de su obra Die Philosophie des Als Ob, publicada en 1911, aunque elaborada décadas antes. Vaihinger distinguía allí esta perspectiva del pragmatismo, para el cual, dice: "una idea que resulta ser útil en la práctica se considera por esto mismo como verdadera en teoría, de manera que lo provechoso siempre es verdadero". 
pensadores medievales como Duns Scoto o Guillermo de Ockham, y modernos como George Berkeley, Thomas Hobbes y Adam Smith; aunque sus dos inspiraciones fundamentales son el constructivismo de matriz kantiana y la filosofía de Nietzsche. ${ }^{4}$ En su análisis de "la voluntad de ilusión" en Nietzsche, Vaihinger advierte cómo ya desde sus primeros escritos, el filósofo prepara el terreno para el reconocimiento de la presencia funcional de la ilusión y la invención en el mundo real. ${ }^{5}$ En sus escritos de madurez, Nietzsche afirma que muchas ideas de cuya falsedad somos conscientes constituyen necesidades biológicas y teóricas; incluso muchas creencias que provienen de la ciencia son "ficciones reguladoras". ${ }^{6}$ Y en los fragmentos póstumos, llama "hipótesis reguladoras" a determinados principios de la ciencia, como las ideas de causa y efecto, que son "hipótesis por medio de las cuales humanizamos el mundo". Para cubrir los objetivos de la vida, el intelecto necesita "como un medio necesario la introducción de ficciones plenas y cabales a título de schémata, que (...) nos permitan imaginar los sucesos como más sencillos de lo que realmente son”; en otras palabras, dice Vaihinger, falsificarlos ${ }^{7}$.

Un lector de Platón no puede sino evocar aquí las recurrentes observaciones que se formulan en los diálogos sobre la necesidad de buscar "falsedades que se hacen necesarias", ${ }^{8}$ el deber de "servirse de un extenso mito", 9 la conveniencia de producir mitos verosímiles, aunque alguno no sea "totalmente concordante consigo mismo ni exacto", ${ }^{10}$ y la necesidad de aceptarlos ${ }^{11}$ como explicaciones razonables acerca de amplias porciones de la realidad. La convicción de los sucesores de Platón en la Academia acerca de su habitual recurrencia a ficciones sapheneías chárin, didaskalías héneka o theorías héneka -es decir, formuladas en beneficio de la claridad, en vistas de la comprensión didáctica o de la teoría ${ }^{12}$ parece ir en la misma dirección. Nietzsche pone de relieve que "el propio Platón concibió así a sus Formas: como ficciones reguladoras". ${ }^{13} \mathrm{Se}$ trata de una lectura interesada, tal vez, pero de ningún modo ilegítima: en el Fedón, Sócrates afirma que, decepcionado de las respuestas que proporcionaba

${ }^{4}$ Vaihinger no reparó en la figura de Jeremy Bentham y su Theory of Fictions. Fue el traductor del Die Philosophie des $\mathrm{Als} \mathrm{Ob}$ al ingles, C. K. Ogden, editor también de la obra de Bentham, quien le advirtió sobre este antecedente. Cf. Ogden 1959, xxxii.

5 Vaihinger 1996, 43-51.

${ }^{6}$ La expresión se encuentra en La gaya ciencia (V, 344).

${ }^{7}$ Cf. Vaihinger 1996, 75-76.

${ }^{8}$ Cf. pseúdos ... en déonti, en República 414b8-9.

${ }^{9}$ Cf. deî megálou mýthou proschrésasthai, en Político 268d9.

${ }^{10} \mathrm{Cf}$. heautoû homologouménos lógos kaì apekkribomenos, en Timeo 29c6.

11 Cf. Timeo 29c7-d3: "Si llegamos a producir [un relato verosímil] no menos verosímil que otros, será necesario alegrarse (agapân chrế), (...) de modo que acerca de esto conviene que aceptemos (apodechoménous prépei) el relato verosímil y no busquemos más allá”.

12 Cf. H. Cherniss 1944, 421-2, sobre la interpretación de Espeusipo, Jenócrates y Crántor acerca del comienzo temporal del universo en el Timeo.

13 En los fragmentos Póstumos (vol. XIII: 323), citado por Vaihinger 1996, 77. 
la filosofía natural, al buscar la causa de por qué una cosa es como es, su procedimiento consiste en proponer una hipótesis, la que le parezca más segura, y entonces a lo que concuerda con ella lo considera "como [si fuera] verdadero". Esta suposición que se pone como base no es otra que "existe algo bello, en sí y por sí, y algo bueno y algo grande y todas las cosas [de ese estilo]"; ${ }^{14}$ la hipótesis es en definitiva que existen Formas, realidades en sí y por sí.

Vaihinger detecta dos influencias notables en el ficcionalismo de Nietzsche: por un lado, El mundo cormo voluntad y representación, de Arthur Schopenhauer, y por otro lado, Friedrich Albert Lange y su historia del materialismo, ${ }^{15}$ de raíz neokantiana. Que la vida y la ciencia "no son posibles sin concepciones falsas o imaginarias" y que se las emplea "inconscientemente en bien de la vida y de la ciencia" son ideas inspiradas por Schopenhauer, "pero que tales ideas falsas puedan ser utilizadas tanto en la ciencia como en la vida por personas intelectualmente maduras con plena conciencia de su falsedad" es algo que Nietzsche llegó a percibir con la lectura de Lange, y su énfasis en la capacidad de la mente creadora, activa, de su actividad inventiva, poética y falsificadora, que es en rigor auténtica "herencia kantiana". ${ }^{16}$ De hecho, cita a Kant cuando afirma que "la razón no deriva sus leyes de la naturaleza sino que las prescribe a la naturaleza"; una frase que, al margen de las lecturas nietzscheanas, es casi imposible no asociar con el modo en que Timeo se refiere a la acción racional y ordenadora del demiurgo sobre el universo. En el relato de Timeo con frecuencia resulta muy difícil de distinguir la descripción de la tarea que lleva a cabo la divinidad demiúrgica de una sutil pero firme prescripción de lo que, desde la perspectiva de la razón humana y tal como Platón la concibe, se supone que el ordenador y productor del cosmos debería hacer.

En las páginas que siguen voy a considerar algunos usos de la ficción en Platón. Voy a plantear en primer término un recorrido más bien general por la historia semántica de las palabras plásso y plásma, las que nos llevan más directamente al ámbito de la ficción. Como veremos, en los siglos V y IV a. C., el vocabulario de la ficción es muy amplio y diverso: incluye nociones que van desde mímesis a pseúdos, de eikasía a mythología. Sin embargo voy a concentrarme en esta primera y literal acepción de plásma como ficción (y de sus derivados) para despejar el concepto de su asociación unidireccional con la literatura, y para tratar de subrayar que su primera incumbencia es filosófica.

14 Cf. Fedón 100a-b y lo que sigue, con la admisión del carácter provisional del método; cf. especialmente hypotíthemi en 100a2, títhemi hos alẹthé ónta, en 100a5. Sócrates pide, además, que se lo siga en su razonamiento; él piensa que "si hay alguna otra cosa bella al margen de lo bello mismo no podría ser bella por ninguna otra cosa sino por participar de eso que es bello por sí mismo" (100c4-6).

15 Geschicthe des Materialismus, 1866, citado por Vaihinger.

16 Vaihinger 1996, 43-44 (quien, por otra parte, reconoce la ferocidad con la que Nietzsche atacó a Kant, y a otros que, no obstante, influyeron tanto o más decisivamente que aquel en su propia filosofía). 
Me voy a concentrar en los usos platónicos de esta familia lexical y luego en ciertas decisivas innovaciones que introduce Aristóteles. En segundo término voy a considerar el caso de las falsedades que "asimilamos a verdades", planteado en República II y III, tomándolo como ejemplo del empleo consciente de ficciones.

\section{FICCIÓN ANTES DE PLATÓN Y EN LOS DIÁLOGOS}

Ni el verbo plásso ("modelar", "forjar") ni el sustantivo plásma, derivado de aquel, aparecen en los poemas homéricos: el verbo sí está atestiguado en Hesíodo; ${ }^{17}$ en Los trabajos y los días se dice que Zeus dio la orden a Hermes de fabricar a Pandora y que enseguida "el dios cojo modeló (plássen) con arcilla una figura semejante a una austera virgen, como quería el Cronida" ${ }^{18}$ Plásso significa "modelar", "formar", y su raíz, plath-, expresa la idea de "extender una capa fina", "enduir", "cubrir". En el griego arcaico y clásico, el verbo y toda la familia de palabras que de él deriva conforman el léxico del trabajo en arcilla y del modelado en cera, y de allí surgen luego una cantidad de términos relativos a la fabricación y a la creación, ya sea manual o mental. Y a partir de esta última se despliegan luego las palabras relativas a los productos de la imaginación. "En condiciones ligeramente diversas", afirma Pierre Chantraine, el sánscrito déhmi y el latín fingo tuvieron desarrollos semejantes. La investigación etimológica todavía "incierta", dice- remite en última instancia a *pela, que expresa la idea de extender sobre algo, ${ }^{19}$ como el pintor extiende sus colores o el escultor la arcilla sobre una superficie. Nos interesa precisamente ver cómo fue que estas palabras comenzaron hablando del modelado en barro y terminaron hablando de nuestra imaginación ficcional.

El modelar al que se refiere el verbo plásso en los primeros usos registrados es un modelado sobre materiales flexibles: en el segundo libro de sus Historias, dedicadas a la cultura egipcia, Heródoto cuenta la leyenda del ave fénix - "poco creíble" para él- que traslada el cadáver de su padre desde Arabia hasta el templo del Sol. Para poder hacerlo, el ave "modela un huevo de mirra" y pone dentro el cuerpo muerto. ${ }^{20}$ Heródoto cuenta también el curioso tratamiento que hacen los egipcios de los cerdos, animales considerados impuros, y de cómo los sacrifican exclusivamente en las festividades de la Luna y de

17 Las referencias a la historia lexical en lengua griega están tomadas del diccionario lexicográfico de H.G. Lidell y R. Scott, revisado por H.S. Jones, 1968 (en adelante, citado como LSJ).

${ }^{18}$ Hesíodo, Trabajos 70-71.

19 Chantraine 1968, 910-911. En la historia de los usos del verbo latino fingo, del sustantivo fictio, y de las formas adverbiales adverbiales fictē y ficticiē se verifica una evolución análoga a la de la familia de plásso/plásma.

${ }^{20}$ Heródoto, Historias 2.73. 
Dioniso por razones que Heródoto juzga "no muy conveniente" referir. Los pobres -explica-, "por su indigencia", para poder honrar a la divinidad "modelan (plásantes) puercos de pasta, los cocinan y los sacrifican". ${ }^{21}$ En cambio, el tipo de artesano que tiene en mente Platón cuando emplea el mismo verbo plásso parece ser de una clase más elevada.

Siempre con el mismo sentido de modelar y dar forma a algún material plástico, en el Timeo, Platón se refiere al origen último de la materia con la metáfora de un orfebre: "Si alguien modelara (plásas) unas figuras en oro y no cesara de transformar cada una de ellas en todas las demás, y si alguien indicara alguna de ellas y le preguntara ¿qué es?...”. ${ }^{22}$ En el libro quinto de las Leyes, el personaje principal propone cómo organizar una colonia que imagina fundar en Magnesia y explica cómo el legislador debería distribuir el terreno en lotes y urbanizar la zona residencial, a qué se dedicará cada uno de sus habitantes y cómo les serán repartidos los bienes. Al término de una larga lista de indicaciones muy precisas, este mismo personaje parece reconocer lo abstracto e impracticable del planteo y afirma que tal vez lo expuesto "nunca vaya a encontrar las circunstancias que permitan que todo llegue a darse como se ha planeado", pero insiste con la pertinencia de que el legislador todo lo exponga "como si contara sueños o plasmara en cera (plátton... ek keroû) la ciudad y los ciudadanos". ${ }^{23}$ Los grandes héroes de la filosofía platónica de la vejez son todos artesanos que forjan manualmente su tarea: el orfebre que da forma a los cuerpos elementales, el educador de la República que modela las almas, ${ }^{24}$ el legislador que fabrica obsesivamente su pólis de plastilina y por supuesto el demiurgo, divino hacedor del mundo entero, es también un artífice que elabora con materiales más sutiles el alma del mundo, modela la parte más excelsa del cuerpo humano, ${ }^{25}$ y luego deja a los artesanos de menor jerarquía la tarea de confeccionar los cuerpos y ensamblarlos a las partes mortales de las almas humanas, fabricadas con los ingredientes sobrantes de la elaboración de la parte divina del alma. ${ }^{26}$

En el origen remoto de nuestra noción de ficción encontramos labores manuales de modelado; derivadamente la familia lexical se va aproximando desde allí al significado de una cierta manipulación de otro tipo de materiales: ya no cera ni barro sino contenidos mentales. Este deslizamiento semántico

\footnotetext{
${ }^{21}$ Heródoto, Historias 2.47.

22 Platón, Timeo 50a5-b1: ei gàr pánta tis schémata plásas ek chrysoû... deiknúntos dé tinos autôn én eroménou ti pot'estí...

${ }^{23}$ Leyes V 746a6-8.

24 Cf. epláttomen en Rep. II 374a5 y pláttein en 377c3.

${ }^{25}$ Cf. plásas, en Timeo 73c8 y 74a2, referido al modelado de la cabeza que recibe la parte divina del alma, y a las vértebras de la médula, respectivamente; y también plasthénti en Tim. $78 \mathrm{c} 3$, a propósito de la confección de las arterias que llevan sangre y aire.

${ }^{26}$ Cf. pláttein, en Timeo 42d6-e1, para referirse a la confección que llevan a cabo los dioses menores.
} 
aparece en diversas fuentes, pero puede rastrearse con mucha mayor claridad en los escritos platónicos. De la idea original de modelar proviene el significado de plásso como "formar", "educar" y también "formar la imagen de una cosa en la mente" o "imaginar". Así lo usa Platón en el Fedro: "Aunque nunca lo hayamos visto ni concebido rectamente, imaginamos - pláttomen - un dios con cuerpo y alma unidos". ${ }^{27}$ También en la República: "Nuestro propósito ahora es imaginar - pláttomen- una ciudad feliz, no estableciendo que unos pocos, a los que segregamos, sean felices, sino que lo sea la totalidad". ${ }^{28}$ En ambos casos se nos propone formarnos una cierta imagen en la mente.

Otro significado atestiguado del mismo verbo, el de "modelar de una cierta manera”, comienza a aplicarse a determinados aspectos de la conducta individual, con el sentido de quien está manipulando las disposiciones que se daban naturalmente: por ejemplo, modelar la voz y pronunciar de una forma más elegante, como aparece en el platónico Crátilo con la pronunciación afectada: "Creo que eso hacen los que no se preocupan para nada de la verdad, sino que modelan (pláttontes) la boca e insertando muchos cambios en los nombres originales logran que nadie comprenda lo que significa una palabra”. ${ }^{29}$ De éste al significado de "falsificar" hay un paso muy corto. Y en efecto, encontramos el verbo plásso con este sentido en textos de la oratoria forense de los siglos $\mathrm{V}$ y IV a. C., y en la platónica Apología de Sócrates: "No crean -les dice el acusado a sus jueces- que a mi edad voy a presentarme ante ustedes como un adolescente que maquilla sus palabras (pláttonti lógous)" ${ }^{30}$ Ese maquillaje al que se refiere Sócrates juega con el manifiesto sentido de falsificar o tapar la verdad.

Por último, encontramos al verbo plásso con el significado de "fabricar mentiras" o "decir cosas inventadas, ficticias u opuestas a lo verdadero". Así aparece el término en Heródoto. En el libro octavo de las Historias, relata el encuentro entre Temístocles y su rival Arístides, que trae información crucial y favorable a los planes del líder ateniense sobre la posición de la flota persa, justo antes de la batalla de Salamina. "Ya que llegas con esa buena noticia -le dice Temístocles-, anúnciala tú mismo; si lo yo digo van a creer que lo inventé (dóxo plássas légein)". ${ }^{31}$ Con el mismo significado encontramos al verbo en los Recuerdos de Sócrates de Jenofonte: "Eres esa clase de amigo -le dice Critóbulo a Sócrates- que me ayuda si tengo alguna cualidad para conquistar amigos, pero si no, no estarías dispuesto a inventar alguna historia (plásas ti eipeîn) para ayudarme". ${ }^{32}$ Por la réplica de Sócrates al reproche - ¿ ¿Te ayudo más haciendo de ti falsas alabanzas o tratando de convencerte de que seas un hombre de

\footnotetext{
27 Pláttomen, en Fedro 246c7.

28 Pláttomen, en República IV 420c2.

${ }^{29}$ Pláttontes, en Crátilo $414 \mathrm{~d} 1$.

30 Cf. Apología 17c6.

${ }^{31}$ Heródoto, Historias 8.80.

32 Jenofonte, Recuerdos de Sócrates II 6.37.
} 
bien?"- es evidente que allí plásso quiere decir "inventar algo falso" o "contrario a la verdad". En el Crátilo también se emplea con este mismo sentido: "Tal vez dirás que este es otro invento mío...”. ${ }^{33}$ Pero probablemente el caso más paradójico de los usos del verbo plásso con el significado de "inventar" sea el que aparece en el Timeo. Justo cuando los interlocutores del diálogo acaban de escuchar de uno de ellos el mito de la Atlántida - sin duda una fabulosa invención platónica-, Sócrates felicita al orador y dice que se alegra por haber podido oír "no un relato inventado sino una historia verdadera". ${ }^{34}$ Antiguos y modernos intérpretes se aferraron a estas crípticas palabras para defender la veracidad de la leyenda de la gesta atlántica. Incluso los primeros navegantes que atravesaron el océano en el siglo XVI quisieron ver allí una prueba de la remota existencia de aquel misterioso continente, que debía estar hundido suponían- a mitad de camino entre el Viejo y el Nuevo Mundo. Posiblemente Platón sólo quería subrayar el valor que tienen las epopeyas heroicas cuando se trata de forjar la propia historia patria; una historia que necesariamente tiene que asumirse como verdadera para que sea eficaz como supuesta memoria de un pasado en común. Ahora nuestro objetivo no es desentrañar los mecanismos con los que Platón busca reforzar la eficacia persuasiva de sus mitologías sino repasar los usos atestiguados de ciertos términos que nos permiten recobrar el camino que va del modelado de la arcilla o la cera a la idea de ficción. Es Platón, una vez más, el que ofrece en sus escritos el hilo conductor que nos lleva desde la noble tarea del orfebre hasta deducir las tres cualidades negativas con las que está investido, desde sus orígenes, el concepto de ficción que deriva de la familia léxica de plásso.

En dos de los diálogos platónicos de la vejez encontramos empleado por primera vez el adverbio plastô̂s, "de manera ficticia" o "de manera fingida", y en estas tres primeras ocurrencias, el ser ficticio se revela como algo opuesto a lo real, contrario a lo verdadero y a lo natural. Al comienzo del Sofista, el personaje al que llama Extranjero de Elea dice que "los que son filósofos realmente (óntoss) y no de manera fingida (plastôs) observan desde lo alto la vida de acá abajo" ${ }^{35}$ En el libro primero de las Leyes, un personaje se refiere a los atenienses y dice que son los únicos "excepcionalmente buenos", pero aclara: "verdaderamente (alethôos), no de manera ficticia (plastôs)"; y en el libro sexto, otro personaje dice que "se puede reconocer claramente al que por naturaleza (phýsei) y no de manera fingida (plastôs) respeta la justicia”. ${ }^{36}$ En estos tres primeros usos del término, lo que se busca subrayar por oposición es una modalidad negativa: unos fingen ser filósofos pero no lo son en realidad; otros aparentan ser justos

\footnotetext{
33 Cf. Crátilo 415d6: kai ísos me âu phéseis pláttein...

34 Cf. Timeo 26e4-5: mè plasthénta mûthon all' alethinòn lógon.

35 Cf. Sofista $216 \mathrm{c} 6$.

36 Cf. Leyes I 642d2-3 y VI 777d6-8.
} 
en lugar de respetar a la justicia de forma auténtica; otros no son verdaderamente buenos sino que disimulan su mezquindad.

Por supuesto que el adverbio aislado, por sí solo, no indica necesariamente algo peyorativo: oponerse a lo naturalmente dado podría ser, en determinadas circunstancias, algo muy positivo; sin embargo, en todos estos empleos que hace Platón del término encontramos la misma clave semántica. Hoy en día, cuando algo del ser ficticio o del uso de las ficciones nos irrita es porque entra en alguna de estas tres formas de oposición sugeridas por primera vez en los diálogos platónicos: nos irrita porque se opone a lo natural y ha sido retocado, modelado, manipulado; porque no es real sino fingido; porque no es verdadero sino falso. Cuando cierto uso de la ficción nos fastidia estamos oponiendo lo real, lo verdadero y el estado de cosas natural a eso otro que alguien modeló, plasmó, elaboró mentalmente, armó, disfrazó, manipuló, fraguó, falsificó.

\section{INNOVACIONES QUE INTRODUCE ARISTÓTELES}

La idea de ficción, así como el problema de determinar lo que es o no ficticio en un relato, pertenecen a la cultura escrita. Por eso no debe sorprender que el vocabulario de la ficción sea relativamente tardío. No aparece en los poemas homéricos -que nacen, se transmiten y llegan a ser el eje de la educación sin terminar de salirse completamente del universo de la cultura oral- $;{ }^{37}$ se insinúa en el mundo todavía arcaico de Hesíodo, y se despliega en la época clásica: el periodo abarcado por los siglos V y IV a. C., en el que la revolución tecnológica de la escritura penetra en todas las áreas de la vida. En la vida política y legal, en las formas de resolver pleitos jurídicos, en la divulgación del saber -que con la multiplicación de los ejemplares escritos pasa a incluir también, por primera vez en la historia, la lectura en silencio-, en los planes y criterios de enseñanza. $\mathrm{Al}$ expandirse el universo de la cultura escrita qué se dice, quién lo dice y cómo lo dice pasan a ser motivo de suspicacia, discusión y debate en la asamblea, en los tribunales, en los gimnasios, en el teatro y en el mercado, los ámbitos que constituyen, cada uno a su manera, diversos centros de educación y de vida social. Y así como suele observarse la relevancia que tiene la pólis, como fenómeno socio cultural, en la formación de grupos de intelectuales, no debe menospreciarse el peso que tiene la escritura en la ampliación de la terminología y de los significados atribuidos al vocabulario del modelado, que de manera notable va asumiendo sentidos relativos a la invención, a la falsificación y a la ficción.

${ }^{37}$ Las investigaciones más recientes sitúan la transcripción de las sagas homéricas en el siglo VI a. C., tal vez durante la tiranía de Pisístrato; cf. al respecto la tesis de J. Signes Cordoñer 2004. 
A excepción del verbo plásso y de muy pocas palabras afines, como el adjetivo plastós -"modelado", "fabricado", y también "falsificado"- que figura en los poemas hesiódicos, prácticamente toda la familia léxica es tardía. Y es tanto más tardía cuanto más se alejan sus términos del significado manual o artesanal originario y se van aproximando semánticamente a la idea de una manipulación o deformación mental o a la de un invento de la imaginación. El sustantivo plásma podría parecer una excepción, ya que aparece con el sentido de "ficción" en un fragmento atribuido a Jenófanes, siglos VI-V a. C., referido a las "ficciones de los antiguos"; sin embargo la fuente que lo transmite es Ateneo, autor del siglo II d. C., por lo que precisar la datación exacta del término se vuelve problemático. Plásso no se usa con significados relativos a la elaboración mental antes del siglo V a. C. Es justamente hacia finales de este siglo V a. C., el que William K. C. Guthrie en su gran Historia de la Filosofía Griega denominó "el siglo de la Ilustración", ${ }^{38}$ que las palabras asociadas con el modelado manual comienzan a significar otro tipo de modelado: elaboraciones mentales, intelectuales y también textuales. Quienes inauguran estos nuevos valores de las palabras más antiguas son los oradores forenses (Demóstenes, Antifonte), los educadores (Isócrates), los autores teatrales (Esquilo, Aristófanes, Sófocles) y, de manera especialmente significativa, Aristóteles. Con ellos, estas viejas palabras del ámbito de la artesanía, como plásso y plásma, adquieren significados nuevos. Pero además se forjan nuevas palabras con sentidos inequívocamente vinculados al mundo de las ficciones: plásis ("invento", "ficción”), plasmatías ("fabricado"), plasmatódes ("ficticio"). El avance imparable de la cultura escrita e "ilustrada" obliga a buscar nuevas expresiones para nombrar realidades discursivas cada vez más frecuentes, que van desde la fabricación de acusaciones en la asamblea o el tribunal a la elaboración de razonamientos abstrusos en la biología o en la astrofísica.

Además de ser consecuente con el uso de plásma como "ficción" o "producto de la imaginación" - un uso que probablemente haya inaugurado él mismo-, ${ }^{39}$ Aristóteles es el que aporta la mayor cantidad de neologismos a este núcleo semántico, dentro de la misma familia lexical. Es razonable y coherente: en la historia de la educación, Aristóteles marca el definitivo paso "de la instrucción oral al hábito de la lectura" ${ }^{40}$ Hasta el siglo IV a. C., la publicación de un libro consistía en su lectura en voz alta ante una audiencia. Hay varios ejemplos de esta práctica atestiguados en las biografías tardo-antiguas: Diógenes Laercio cuenta alguna bastante socarrona, incluso, sobre el aburrimiento generalizado que produjo la primera lectura en público del Fedón de

38 Cf. W. K. C. Guthrie 1994, xviii.

${ }^{39}$ La única ocurrencia anterior que registra el LSJ es el fragmento de Jenófanes comentado en el párrafo anterior.

40 Cf. Frederic Kenyon 1951, 25. 
Platón. ${ }^{41}$ Aristóteles, en cambio, además de participar hasta el final del espectáculo del lanzamiento editorial del Fedón, se acostumbró a leer los libros de sus contemporáneos y de sus predecesores, y a ficharlos por temas, como él mismo cuenta en algunos de sus escritos. Por eso Ingemar Düring considera totalmente verosímil y justificada la leyenda del sobrenombre, "el lector", que el filósofo se había ganado entre sus compañeros desde los tiempos en que estudiaba en la Academia platónica. ${ }^{42}$

Resulta notable constatar que cuando emplea el vocabulario del plásso/plásma, Aristóteles no se refiere nunca a la literatura: plásma, plasmatías, etc. no aluden a narrativas que hoy consideramos literarias. En general, cuando se refiere a la tragedia, el género literario que más interesa a Aristóteles, o a su tema real o imaginario usa la palabra mýthos. En cambio, usa plásma ("ficción”) y otros términos de la misma familia para calificar los argumentos, las hipótesis o las teorías científicas de otros filósofos. Así, en el De Caelo, cuando analiza las tesis astronómicas que proponen la alternancia de una fase más rápida y otra más lenta del movimiento de rotación del universo, dice Aristóteles que "esto es totalmente ilógico y semejante a una ficción”. ${ }^{43}$ En el De generatione animalium analiza diversas hipótesis sobre el desarrollo embrionario: ¿el embrión y el adulto ya están prefigurados en el huevo?, ¿o el huevo es sólo el material a partir del cual se forma el organismo? Aristóteles es partidario de este último razonamiento, porque el otro -dice- "es absurdo y ficticio" (plasmatías). En el mismo tratado, al comentar diferentes teorías sobre la herencia, de una de ellas, la que atribuye aportes de ambos progenitores, observa: "esta explicación no es clara y en muchos aspectos, una ficción" (plasmatías). Y cuando discute las teorías sobre la generación, dice que Empédocles plantea un "tipo de causa ficticio" (plasmatódes). ${ }^{44}$

En los escritos en los que trata acerca de los primeros principios de todo lo real, Aristóteles también emplea a la familia lexical del plásso para desautorizar a una posición filosófica y además revela, en un pasaje breve y notable, su propia conciencia de estar dotando al vocabulario filosófico de un término o por lo menos de un significado novedoso. En el anteúltimo libro de la Metafísica, Aristóteles ataca a los sucesores de Platón en la Academia, Espeusipo y a Jenócrates, y en general a los platónicos que consideran que ciertos entes matemáticos, como los números, son los principios de todo: por un lado, descarta que estas entidades puedan existir en lo sensible: "la teoría de que existen [de

${ }^{41}$ Diógenes Laercio, Vida de los filósofos ilustres III 37: "Favorino cuenta en algún lado que sólo él resistió junto a Platón durante su lectura de Sobre el alma, pero que todos los demás se levantaron y se fueron"; se refiere al Fedón, aunque lo llame con el subtítulo impuesto por los editores del corpus platonicum en época imperial.

42 I. Düring 1966.

43 Cf. pantelôs álogon kaì plásmati hómoion, en De Caelo 289a6.

${ }^{44}$ Cf. Aristóteles, De generatione animalium, 764b10, 734a33 y 769a36. 
este modo] es una fantasía (plasmatías ho lógos)"; pero además considera que los platónicos se aferran a las realidades matemáticas porque reconocen "la dificultad y el carácter ficticio (plásin) de la teoría de las Ideas” de su maestro. En el capítulo siete de ese mismo libro, Aristóteles protesta: postular la existencia de números ideales a partir de cierta definición de las unidades "es algo absurdo y ficticio", y haciendo explícita su innovación aclara: "llamo ficticio (plasmatôdes) a lo que se introduce a la fuerza para acomodarlo a una hipótesis". 45

\section{LA VERDAD DE LAS FICCIONES}

Determinadas pretensiones absurdas de fundar lo real merecen para Aristóteles ser calificadas como ficción. De hecho, consideramos que algo es ficticio porque entendemos que no es real. "Decir de una noción que es ficción es negarle al menos unos grados de realidad y algo de verdad", comenta Jean-Pierre Cléro, precisamente al analizar las dificultades que comporta definir a la ficción. "Pero paradojalmente -sigue Cléro- esto también implica situarla en relación con lo real hasta hacer de ella una cierta condición de lo real, y en relación con los criterios de verdad y falsedad que no se pueden escindir de otros criterios: su dimensión constructiva, su utilidad o incluso otros. Esto hace que la admisión o el rechazo de las ficciones por falaces no dependan sólo de su verdad o de su falsedad. Verdad o falsedad se ponen en relación con otros valores; y un valor desacreditado desde el punto de vista de su verdad puede ser aceptado por otras razones" ${ }^{46}$ Quisiera analizar en este último apartado uno de los casos en los que Platón aboga por la admisión de ciertas ficciones cuya falsedad es indiscutida y que sin embargo deberíamos aceptar por su utilidad práctica. Se trata de ciertos relatos míticos sobre los antiguos, que pueden convertirse en la historia de un pasado compartido y el punto de partida para la convivencia en la pólis. Hasta tal punto esas falsedades son convenientes y necesarias que Platón llega a considerarlas verdaderas. Trataré de mostrar que esta aparente contradicción o indecisión respecto del estatuto de verdad de ciertos relatos no es tal si se la estudia como un esbozo todavía esquemático y algo críptico de una incipiente teoría de las ficciones.

En República II y III, en el marco de una amplia discusión sobre la educación de los guardianes que tendrán que conducir el saneamiento de la pólis corrupta, Platón critica el arte poético: objeta algunos aspectos formales (métrica, dicción, ritmo) pero las críticas se dirigen especialmente al contenido de las historias de los poetas. Sobre todo las de Homero, gran aedo y educador de la Hélade. Platón no impugna el arte ni mucho menos el hecho de que

45 Plasmatías en Metafísica XIII 1. 1076a39; plasmatôdes en Metafísica XIII 6. $1082 \mathrm{b3}$.

46 J.-P. Cléro 2014, vii. 
Homero y otros cuenten relatos que hoy llamaríamos ficticios, cosas inventadas, sino los valores que algunos relatos poéticos transmiten a los griegos. ${ }^{47}$ Platón es un escritor él también, y escribe casi exclusivamente ficciones: ${ }^{48}$ sus diálogos son piezas dramáticas, no relatos de sucesos reales, y en ellos el marco ficcional es siempre relevante para el problema filosófico a tratar. Si objeta aquí a otros poetas es porque reclama para sí -o para la filosofía- el papel del genuino educador: una pólis sólo podrá llegar a ser justa si se le confía a la disciplina filosófica, y no a la poesía tradicional, la guía y formación de sus ciudadanos.

En ese contexto, y a propósito del enorme valor formativo de las historias míticas, Platón distingue en República II entre dos clases de mentira o falsedad (pseúdos). La "verdadera falsedad" es la del "estar engañado en el alma con respecto a la realidad". ${ }^{49}$ Se trata de una forma de ignorancia: uno está engañado y cree como verdadero algo que en realidad es falso. La otra clase, la "falsedad en las palabras", es "una imitación" de la primera, y no implica la propia ignorancia respecto de la verdad sino sólo el empleo verbal de una falsedad. Aunque Platón no habla en estos términos podemos entender a la primera clase como falsedad inconsciente (se afirma una mentira ignorando que se desconoce la verdad) y a la segunda como falsedad consciente: se afirma algo a sabiendas de que eso no es, en rigor, verdad sino algo que eventualmente puede "asimilarse a la verdad" y llegar a convertirse así en "un remedio útil” aunque, obviamente, el resultado de la asimilación no pueda garantizarse a priori. Sócrates ilustra la utilidad que puede tener esta falsedad que llamé consciente con el ejemplo de quien está frente al enemigo, o junto al amigo que está por cometer algo malo por un arranque de locura o insensatez; ${ }^{50}$ ante ellos sería razonable proferir una falsedad consciente. Pero Platón no está pensando aquí sólo en amigos enojados sino, sobre todo, en la legitimidad del uso político de ciertas falsedades; de ciertas ficciones. Esto es lo que va a concluir, precisamente, en el libro siguiente, República III, cuando plantee el relato manifiestamente ficticio de los hombres nacidos de la tierra pero forjados con diferentes metales. Por el momento, una vez planteada esta crucial distinción entre diferentes tipos de falsedad, su razonamiento retoma el análisis de lo que hacen los poetas. La composición de mitos

47 Critica por ejemplo el efecto que tendría en la educación de guardianes, "que deben temer más a la esclavitud que a la muerte", la idealización de héroes que muestran miedo y cobardía. Cf. Rep. III 386a-389b.

48 "Casi exclusivamente" porque dejamos de lado a la Apología de Sócrates, que reproduce más o menos fielmente el discurso forense de Sócrates, y a las cartas, sean o no auténticas. Fuera de estos escritos, todos los demás que integran el corpus platonicum son ficciones.

${ }^{49}$ Cf. República II 382a-b.

${ }^{50}$ Cf. República II 382c. 
(mythología) -afirma- es un caso de falsedad en las palabras, ya que "por desconocer hasta qué punto son verdaderos los hechos de los antiguos, asimilamos la falsedad lo más posible a la verdad y la volvemos útil". ${ }^{51}$

Con mythología Platón se refiere a las historias que transmite la poesía (la épica, la lírica, también la tragedia), y que en buena medida constituyen el relato compartido acerca del pasado, a la manera de historia remota y ancestral de los griegos. ${ }^{52}$ Puesto que no podemos conocer cabalmente ese pasado remoto, y por tanto tampoco decir la verdad sobre él, empleamos falsedades, "asimilándolas lo más posible a la verdad" y "volviéndolas útiles". No son verdades sino falsedades, pero podemos revalorizarlas por su utilidad. La determinación de su valor no está dada por su adecuación con los hechos antiguos, puesto que se advirtió previamente que no podemos conocerlos, de modo que "asimilarlas lo más posible a la verdad" significa volverlas funcionales. Su verdad es, en rigor, valor práctico. Como señalaba Cléro respecto de las ficciones, estas falsedades conscientes, desacreditadas desde el punto de vista de su verdad fáctica, encuentran su aceptación en razones de utilidad. De hecho, Sócrates apunta a hacer de ellas algo positivo, una "noble mentira". ${ }^{53}$ Cuando retoma, en República III, el discurso anterior sobre las mitologías se refiere a ellas precisamente como "falsedades que se hacen necesarias". ${ }^{54}$ Introduce entonces un "cuento fenicio" sobre el origen de los atenienses: el relato de los metales, que tiene por objetivo persuadir a los ciudadanos acerca de su origen común, autóctono y fraterno, pero a la vez diferenciado según disposiciones naturales. Este tipo de falsedades aceptables -legítimas, invenciones necesarias- son entonces, en este sentido, ficciones. En las primeras décadas del siglo XX algunos grandes intérpretes del

51 Cf. República II 382d1-3: dià tò mè eidénai hópe tàlêthès échei perì tôn palaiôn, aphomoioûntes tôi alêthể tò pseûdos hóti málista, hoúto chrésimon poioûmen; La expresión "asimilando las falsedades lo más posible a la verdad” podría ser alusión a Hesíodo, Teogonía 28-29: "Sabemos decir mentiras con apariencia de verdades y sabemos, cuando queremos, proclamar la verdad".

52 Una cuestión aparte, que Platón no trata explícitamente en los diálogos, es qué clase de fe le presta a Homero su audiencia. ¿Se trata sólo de una fe poética o también de alguna clase de fe histórica? Es decir: los lectores / oyentes de Homero, ¿creen esas historias al menos en cierta medida como historia fáctica? Es obvio que Platón observa la poética de Homero como poética y no como historia, tal como revelan sus referencias a los "personajes" y, en general, sus objeciones a la moral implícita de los relatos épicos. Sin embargo, el valor de la épica homérica para la historia es más ambiguo. En su estudio sobre la antigua historiografía, James Shotwell (1961) sugiere que fue la extraordinaria calidad de los poemas homéricos lo que retrasó el desarrollo de una disciplina científica histórica. La épica funcionaba como fuente principal a la que se dirigían los griegos cuando querían conocer sobre su pasado. Era una obra artística, imaginaria, que mezclaba "sueños y realidades", pero como estaba tan bien escrita - dice Shotwell- inhibió la búsqueda de otros tipos de narrativa.

53 Cf. República III 414b-c: tís àn hemîn, ên d'egó, méchanè génoito tôn pseudôn tôn en déonti gignoménon, hôn dè nûn elégomen, gennaîón ti èn pseudoménous pê̂́ai málista mèn kaì autoùs toùs árchontas, eidè mé, tén állen pólin;

${ }^{54} \mathrm{Cf}$. 414c: tôn pseudôn tôn en déonti gignoménon. 
pensamiento platónico se aventuraron a traducir en este marco pseûdos como "ficción". ${ }^{55}$ Christopher Gill cuestionó esta asociación en un influyente ensayo.

Si bien Gill no niega "que el status adscripto a la falsedad en los lógoi, como la de la mythología y la noble mentira son en nuestros términos ficcionales, al menos en cuanto al tipo de narrativa elaborada o fabricada conscientemente", ${ }^{56}$ considera sin embargo que todo el tratamiento bien puede ser analizado en términos de verdad y falsedad. Objeta entonces aquella identificación por dos razones: en primer lugar porque, dado que en República la distinción verdadero-falso "no se usa para diferenciar entre discurso fáctico de ficcional", 57 entonces esa falsedad de la que habla Sócrates no debería entenderse como "ficción". En segundo lugar, Gill sostiene que "el innovador uso platónico de la noción de falsedad no ha sido pensado para caracterizar lo que podríamos llamar la dimensión ficcional de la creatividad poética" ya que "mucho de lo que Platón critica como falsedad de la poesía corresponde a algo que nosotros valoramos en la ficción: la extensión imaginativa de nuestra experiencia personal, de nuestras actitudes y valores" ${ }^{58}$ Yo encuentro, en cambio, motivos para desestimar estos dos argumentos y reivindicar el uso novedoso en Platón de la falsedad como ficción en filosofía.

Empiezo por el último de los dos que propone Gill. En los textos que estamos considerando aquí -fundamentalmente República II y III-, Platón no objeta a la poesía por emplear la fantasía y la imaginación (que son, por otra parte, marcas de muchas de las propias mitologías platónicas, como las coloridas mitologías escatológicas), sino por los valores políticamente inconvenientes que transmite determinada poesía, en su rol de formadora y educadora. En este sentido, Platón no se opone de suyo a la "extensión imaginativa de nuestra experiencia personal” que es propia de la poesía. Al contrario, los mitos platónicos del más allá, como muchas otras de sus metáforas y ficciones (el carro alado, la caverna, etc.), son todos altamente imaginativos, y se piensan como herramientas que extienden nuestra capacidad especulativa, siempre en vista de nuestras actitudes y valores. Pero Platón reivindica para sí -es decir, para la filosofía, y en esto radica la rivalidad con los poetas- la tarea de delinear esas ficciones según los criterios que dicta una determinada concepción éticopolítica, considerada recta "por naturaleza" ${ }^{59}$

${ }^{55}$ C. Gill cita a Lee, Grube, Shorey (Gill 1993, 46).

${ }^{56}$ C. Gill 1993, 55.

57 Gill 1993, 46. A pesar de que la diferenciación entre fáctico o ficcional "ya había sido bien articulada en tiempos de Platón", dice Gill, "aquí Platón no reformula esa distinción".

${ }^{58}$ Cf. Gill 1993, 47.

${ }^{59}$ Cf. República V 456b11-c2, donde se caracteriza al programa político allí propuesto, a la "ley" (nómos), como algo plenamente "conforme a la naturaleza" (katá phýsin). Véase allí también, en Rep. V 468c-d, cómo se rehabilita a Homero, en la medida en que algunos de sus 
En cuanto a la falta de correspondencia que hay en República II-III entre verdadero/falso y fáctico/ficcional, que es el otro punto que señala Gill, ella no puede emplearse en contra de la identificación de falsedad y ficción justamente porque se trata de una correspondencia que Platón rechaza desde el comienzo de su argumentación. La historia remota que cuenta la mitología no es verdadera por ser fáctica ni es falsa por no serlo. En el razonamiento platónico, verdadero no equivale a fáctico ni falso a lo que se opone a lo fáctico, ya que su perspectiva no es la de la verdad como constatación de hechos pasados. Semejante posibilidad es descartada de plano al inicio de la reflexión sobre las mitologías: forjamos falsedades que asimilamos a la verdad precisamente "porque no podemos conocer los hechos del pasado". ${ }^{60} \mathrm{La}$ asimilación consiste en convertir esa falsedad consciente -justamente una ficción: lo que Vaihinger llama "lo conscientemente falso" - en herramienta educativa. Cuando en República III Sócrates se dispone a contar su propia falsedad consciente, el "cuento fenicio" de los metales, reconoce de manera explícita que su tarea más difícil es persuadir. ${ }^{61}$ El desafío de su falsedad consciente no consiste en ofrecer improbables verdades fácticas sobre un pasado remoto que -ya se ha dicho- resulta irrecuperable, sino en la eficacia persuasiva de su invención. ${ }^{62}$

Cuando el Sócrates platónico reivindica el asimilar las falsedades lo más posible a la verdad (Rep. II 382d1-3) no pretende hacer pasar el cuento fenicio por verdad fáctica sino ofrecer un relato persuasivo que tenga fuerza de cohesión y a la vez eduque en los valores que se quieren imprimir en la pólis. La verdad implícita en la expresión asimilar a la verdad es, en rigor, corrección teórico-práctica, es decir: recta concepción teórica y fuerza de convicción que enfatice ciertos valores. ${ }^{63}$ Desde esta perspectiva, las falsedades sí son ficciones:

valores -en este caso, los premios y castigos que reciben en su poema los héroes militaresreflejan la misma concepción teórica platónica.

${ }^{60} \mathrm{Cf}$. República II 382d1-2: dià tò mè eidénai hópei talethès échei perì tôn palaiônn...

61 Cf. República III 414c-d: “...se necesita mucho poder de persuasión para llegar a convencer. (...) Bien, lo contaré, aunque no sé hasta dónde llegará mi audacia ni a qué palabras recurriré para expresarme y para intentar persuadir, primeramente a los gobernantes y a los militares, y después a los demás ciudadanos, de modo que crean que lo que les hemos enseñado y les hemos inculcado por medio de la educación eran todas cosas que imaginaban y que les sucedían en la tierra”.

${ }^{62}$ En su ensayo sobre los mitos platónicos, al comentar este mismo texto, el relato de los metales, afirma Franco Ferrari: "La falsedad concierne a hechos pasados no sujetos a verificación; por otra parte, ella se sitúa en el ámbito de la dimensión de la persuasión (peithô y está dirigida a los ciudadanos: a los gobernantes, por cierto, pero sobre todo a todos los que deben ser gobernados” (F. Ferrari 2006, 32-33).

${ }^{63}$ La imagen que ofrece El Ateniense en Leyes I 644d7-645b8, la de los seres humanos como marionetas, que actúan tensados por dos tipos de cuerdas: las de hierro que son las de los impulsos pasionales, y la cuerda áurea, más débil, que es la del impulso racional a la virtud, también se reconoce como un relato ficticio sobre la virtud (ho mûthos aretêss, en 645b1-2) que transmite sin embargo el razonamiento -o discurso- verdadero (tòn ... lógon alethê , en 645b4-5) acerca de estos impulsos, ya que se funda en la recta concepción acerca de lo que nos lleva a ser o no virtuosos. Agradezco la generosa sugerencia de este pasaje a Gabriela Rossi, así como otras 
elaboraciones de historias cuya verdad no radica en haber ocurrido efectivamente sino en su potencial teórico y práctico.

Christopher Gill parece echar de menos aquí una formulación propiamente platónica de la distinción entre fáctico y ficcional. Pero en cierta medida, en la crítica a los poetas de República II y III, Platón da por supuesta esa distinción cuando admite que desconocemos la verdad acerca de "los hechos de los antiguos" y que por eso forjamos falsedades que asimilamos "lo más posible a la verdad". Lo interesante de su planteo es, sin embargo, la reformulación de la noción de falsedad entendida en esta doble valencia: como pura ignorancia o como ficción. Al distinguir entre una modalidad consciente y otra inconsciente, el análisis platónico de la falsedad retoma la concepción socrática del error y se aventura más allá de ella. La falsedad que aquí llamamos inconsciente equivale a estar "engañado en el alma", a estar en el error. La ignorancia es, según Platón, la verdadera falsedad, porque quien está en el error se engaña a sí mismo. Justamente esta "conexión estructural entre error y autoengaño", el hecho de que "en toda forma de error hay esencialmente un componente irreductible de autoengaño", es lo que advierte la tesis socrática del error. En un ensayo a ella dedicada, Alejandro Vigo la formula así: "a quien está en el error, y en la medida precisa en que lo está, el error no se le revela como error, sino que se le aparece más bien como lo contrario, es decir, como genuino saber". ${ }^{44}$ Ahora bien, en República II, partiendo de este primer análisis de cuño socrático, lo que hace Platón es deslindar el aspecto cognitivo de la falsedad (en el que falsedad equivale a ignorancia y, por lo tanto, a error) de su aspecto pragmático, en el que la falsedad, entendida como una de las plásticas posibilidades del lógos, es evaluada dentro del campo más vasto de la praxis humana. Hay lógoi falsos que sin embargo se asimilan, por su valor práctico, a verdades. En este sentido, Platón da un paso muy claro hacia el ficcionalismo.

"iQué bien te sale componer historias egipcias y de cualquier otra parte que quieras!”, exclama Fedro, en el diálogo que lleva su nombre, ${ }^{65}$ tras escuchar el relato de Sócrates sobre el origen de la escritura. La réplica puede incluirse en la misma consciencia explícita -y toma de distancia- de Platón respecto de su propia producción y uso de ficciones. La historia egipcia puede ser un invento, pero su valor de verdad radica en la enseñanza que deja acerca del tema en cuestión; en el caso del Fedro, la sabiduría aparente, no real, de lo escrito. ${ }^{66}$ Algo análogo ocurre en el Menón. Al final del ejercicio con el esclavo, una vez que la idea de la reminiscencia permite salir de la aporía (es imposible conocer

que ella y los evaluadores anónimos hicieron, y que me ayudaron a clarificar varios puntos de este trabajo.

64 Esta tesis es "sin duda, uno de los aportes más decisivos de Sócrates al pensamiento filosófico occidental”. Cf. respecto de ésta y de las otras citas en el texto, A. Vigo 2013, 15.

65 Cf. Fedro 275b.

66 Cf. todo el pasaje: Fedro 274c-277c. 
partiendo de la ignorancia), el Sócrates platónico toma distancia de la hipótesis de que el alma existe y conoce todo antes de vivir en el cuerpo. "En cuanto a lo demás, no defendería por la fuerza mi explicación (lógos), pero que nos hacemos mejores, más valientes y menos flojos si pensamos que debemos indagar lo que no sabemos (...) por eso sí que daría una batalla”, ${ }^{67}$ afirma.

Esta consciencia de Platón frente al uso de narrativas ficcionales recuerda la aguda distinción que propone Frank Kermode entre ficciones y mitos: mientras que las ficciones sirven para descubrir cosas, cambian junto con las necesidades a las que se ha de hallar sentido y no exigen aceptación incondicional, los mitos, en cambio, presuponen explicaciones totales y exigen aceptación absoluta. ${ }^{6}$ Platón, que reconoce el carácter artificial y en cierta medida provisional de sus ficciones, mira con cautela y pone distancia irónica frente a algunos de estos mitos totalizadores. El pasaje que dedica en el Timeo a las teogonías de la religión olímpica es revelador al respecto: "Decir y conocer el origen de las otras divinidades es una tarea que va más allá de nuestras fuerzas. Hay que creer, por lo tanto, a los que hablaron antes, dado que como descendientes de dioses, como afirman, supongo que al menos conocerían bien a sus antepasados. No es posible desconfiar de hijos de dioses, aunque hablen sin demostraciones verosímiles ni necesarias, sino que siguiendo la costumbre, debemos creerles cuando dicen que relatan asuntos familiares". ${ }^{69}$ La filosofía platónica no renuncia a las ficciones narrativas (ni a otras clases de relatos ficcionales: hipótesis, explicaciones verosímiles, postulados teóricos). Pero a las historias familiares, habitualmente proclives a la exageración y a la arbitrariedad que imponen los lazos afectivos, las deja fuera de su campo de acción.

\section{BIBLIOGRAFÍA}

\section{Instrumentos léxicos}

H.G. Lidell y R. Scott. 1968. A Greek-English Lexicon. With a new edition by H.S. Jones, Oxford, Clarendon Press.

Chantraine, P. 1968. Dictionnaire Étimologique de la Langue Grecque. Histoire des Mots (4 vol.), París, Éditions Klincksieck.

\section{Edición y traducciones de los diálogos}

Burnet, J. 1903-1995. Platonis Opera, I-VI, Oxford, Oxford Classical Texts.

Eggers Lan, C. 1986. República, en Platón, Diálogos IV, Madrid, Gredos.

67 Cf. Menón 86b y las observaciones sobre el carácter hipotético del lógos de la reminiscencia de A. Gómez Lobo 2002, 56 y 76.

68 Cf. F. Kermode 1983, 46-47. En su análisis, Kermode también señala que las ficciones pueden degenerar en mitos cuando no se las considera conscientemente como invenciones.

${ }^{69}$ Cf. Timeo 40d-e y la nota ad locum de C. Eggers Lan 1999, 128. 
Eggers Lan, C. 1999. Platón - Timeo (trad., introd. y notas de C. E. L.), Buenos Aires, Colihue.

Gómez Lobo, A. 2002. Platón - Menón (trad., análisis y notas de A. G. L.), Santiago de Chile, Editorial Universitaria.

Lisi, F. 1996. Timeo, en Platón, Diálogos VII, Madrid, Gredos.

Lisi, F. 1999. Leyes, en Platón, Diálogos VIII-IX, Madrid, Gredos.

Vigo, A. 2012. Platón - Fedón (trad., introd. y notas de A. V.), Buenos Aires, Colihue.

\section{Edición y traducciones de Aristóteles}

Ross, W. D. 1924. Aristotle's Metaphysics, Oxford, Clarendon Press.

Candel, M. 1993. Aristóteles, Acerca del cielo (trad., introd. y notas de M.C.), Madrid, Gredos

Peck, A. L. 1943. Aristotle - Generation of Animals (transl. by A. L. P.), Cambridge, Harvard University Press.

Zucchi, H. 2004. Aristóteles - Metafísica (trad., introd. y notas de H. Z.), Buenos Aires, Sudamericana.

\section{Bibliografía secundaria citada}

Cléro, J.-P. 2014. Essai sur les fictions, Paris, Hermann.

Düring, I. 1987. Aristóteles. Exposición e interpretación de su pensamiento, México, FCE.

Ferrari, F. 2006. I miti di Platone, Milano, Rizzoli.

Gill, C. 1993. "Plato on Falsehood-not Fiction", en C. Gill y T. Wiseman (eds.), Lies and Fiction in the Ancient World, University of Exeter Press, pp. 3887.

Guthrie, W. K. C. 1994. Historia de la filosofía griega, vol. III: Siglo V - Ilustración, Madrid, Gredos.

Kenyon, F. G. 1951. Books and Readers in Ancient Greece and Rome, Oxford, Clarendon Press.

Kermode, F. 1983. El sentido de un final, Barcelona, Gedisa.

Ogden, C. K. 1959. Bentham's Theory of Fictions. Paterson, NJ: Littlefield, Adams.

Shotwell, J. 1961. The Story of Ancient History, Nueva York, Columbia University Press.

Signes Cordoñer, J. 2004. Escritura y literatura en la Grecia arcaica, Madrid, Akal.

Vaihinger, H. 1996. "La voluntad de ilusión en Nietzsche", Apéndice a F. Nietzsche, Sobre verdad y mentira en sentido extramoral, Madrid, Tecnos.

Vigo, A. 2013. "La conciencia errónea: De Sócrates a Tomás de Aquino", en Signos filosóficos 15.29, pp. 9-37. 